BULLETIN OF POLTAVA
STATE AGRARIAN
ACADEIMI

\author{
V. V. Hanhur* \\ Y. O. Kotliar
}

ORCID (iD) 0000-0002-5619-492X

Poltava State Agrarian Academy, 1/3, Skovorody str., Poltava, 36003, Ukraine

*Corresponding author

E-mail: volodimirgangur@gmail.com

How to Cite

Hanhur, V. V., \& Kotliar, Y. O. (2021). Influence of predecessors on water consumption and productivity of winter wheat in the zone of the Left-Bank Forest-Steppe of Ukraine. Bulletin of Poltava State Agrarian Academy, (1), 122-127. doi: 10.31210/visnyk2021.01.14

Winter wheat (Triticum aestivum L.) is a strategic grain crop, which ensures food security of the state. Constantly growing demand for winter wheat encourages the search for ways to increase its yield and improve quality indicators while reducing the cost of a unit of marketable products. Possible measures to stabilize winter wheat production include its place in scientifically substantiated crop rotation system. The aim of the study was to determine the effect of different predecessors, fertilization levels on water consumption of winter wheat plants and its productivity. The studies were conducted at Poltava State Agricultural Research Station named after M. I. Vavilov during 2019-2020. It has been found out that the most available moisture in the 1.5-meter soil layer at the time of resuming spring vegetation was accumulated at sowing winter wheat on black fallow of $250.9 \mathrm{~mm}$. Sainfoin, as a fallow land wheat predecessor, was only $2.9 \%$ inferior to black fallow in terms of moisture reserves. Sufficient reserves of available moisture were accumulated at sowing winter wheat after pea for grain in crop rotation, but they were lower than fallow predecessors by 6.8$13.8 \mathrm{~mm}$ or $2.8-5.6 \%$. The worst conditions for moisture accumulation in the soil were formed during sowing winter wheat after winter wheat. It has been found out that pea for grain was the best predecessor of winter wheat, the yield made $4.52 \mathrm{t} / \mathrm{ha}$ at applying $N_{50} P_{50} K_{50}$ under the crop. Sainfoin per mowing was almost equal predecessor for wheat. Grain yield was by only 1.2\% lower as compared with post-pea for grain cultivation. Sowing winter wheat on black fallow was effective only in dry years. In favorable years as to moistening, a decrease in the yield of winter wheat on black fallow was registered as a result of early and intensive lodging of crops. It has been determined that cultivating winter wheat after winter wheat in crop rotation is undesirable because it leads to yield decrease by $28.0-34.5 \%$ in comparison with better predecessors.

Key words: soft winter wheat (Triticum aestivum L.), predecessors, crop rotation, water consumption, available moisture, yield.

\title{
ВПЛИВ ПОПЕРЕДНИКІВ НА ВОДОСПОЖИВАННЯ ТА ПРОДУКТИВНІСТЬ ПШЕНИЦІ ОЗИМОЇ В ЗОНІ ЛІВОБЕРЕЖНОГО ЛІСОСТЕПУ УКРАЇНИ
}

\section{В. В. Гангур, Я. О. Котляр}

Полтавська державна аграрна академія, м. Полтава, Україна

Стратегічною зерновою культурою, яка забезпечує продовольчу безпеку держави, є пшениия озима (Triticum aestivum L.). Постійно зростаючий попит на зерно пшениці озимої спонукає до пошуку 


\section{СІЛЬСЬКЕ ГОСПОДАРСТВО. РОСЛИННИЦТВО}

шляхів як підвищення ї̈ врожайності, так і покращення якісних показників. Метою досліджень було з'ясувати вплив різних попередників, рівня удобрення на водоспоживання посівів пшениці озимої та їі продуктивність. Дослідження, проведені на Полтавській держсавній сільськогосподарській дослідній станиії імені М. І. Вавилова впродовж 2019-2020 рр., доводять, щяо найбільше доступної вологи в 1,5 метровому шарі трунту на час відновлення весняної вегетації нагромаджувалось у разі розміщення пшениці озимої по чорному пару 250,9 мм. Еспариет як парозаймаючий попередник пшениці поступався чорному пару за запасами вологи лише на 2,9\%. У разі розміщення пшениці озимої в сівозміні після гороху на зерно акумулювалось достатні запаси доступної вологи, однак вони були нижчими порівняно з парозаймаючими попередниками на 6,8-13,8 мм або 2,8-5,6 \%. Найгірші умови для нагромадження вологи у трунті формувалися за сівби пшениці озимої після пшениці озимої. Встановлено, що крашим попередником пшениці озимої є горох на зерно, де в разі внесення під культуру $N_{50} P_{50} K_{50}$ урожайність зерна становила 4,52 $\mathrm{m} / 2$. Практично рівночінним попередником для пшениці є еспарцет на один укіс. Урожайність зерна була нижчою порівняно з розміщенням після гороху на зерно лише на 1,2\%. Розміщення пшениці озимої по чорному пару було ефективним лише в посушливі роки. У сприятливі за зволоженням роки спостерігається зниження урожайності пшениці озимої по чорному пару в результаті раннього і інтенсивного вилягання посівів. Встановлено, щзо небажаним $\epsilon$ розмімення в сівозміні пшениці озимої після пшениці озимої, яке призводить до зниження урожайності порівняно з кращими попередниками на 28,0-34,5\%.

Ключові слова: пшениия м'яка озима (Triticum аestivum L.), попередники, сівозміна, водоспоживання, доступна волога, урожайність.

Вступ

Основною зерновою культурою України є пшениця озима (Triticum aestivum L.), важливість якої обумовлена тим, що вона завдяки високим валовим зборам і цінним якісним властивостям зерна забезпечує продовольчу безпеку держави. Щорічно зростаючі потреби у продовольстві спонукають виробників сільськогосподарської продукції до збільшення обсягів виробництва зерна пшениці озимої 3 високими якісними характеристиками за умови одночасного підвищення показників економічної ефективності технологій ії вирощування.

Найбільш доцільним агротехнічним заходом стабілізації землеробства $є$ впровадження та чітке дотримання науково-обгрунтованих сівозмін. Вони істотно впливають на водний, поживний режими, зменшення шкодочинності бур'янів, дають змогу ефективно використовувати землі, підвищувати енергетичний потенціал грунту тощо $[1,12]$.

Пшениця озима досить вимоглива до місця розміщення у сівозміні. Тому склад і якість попередників пшениці озимої відіграє одну з найважливіших ролей у забезпеченні біологічних вимог культури для формування високих, сталих врожаїв i, особливо, якісних показників зерна $[2,5,11]$.

Наукові дослідження свідчать, що в посушливих умовах півдня України кращий попередник для пшениці озимої - чорний пар, після якого у грунті формується кращий гідрологічний режим та залишається більше рухомих форм азоту, ніж після непарових попередників $[14,19]$.

Дослідження, проведені в умовах Південного Степу України свідчать, що в разі розміщення пшениці озимої після кукурудзи на силос і пшениці озимої врожайність зерна в середньому зменшилася, відповідно на 38,9 і 35,7 \% порівняно з паром. За умови вирощування пшениці озимої на удобреному фоні урожайність культури після вищезазначених непарових попередників також поступалася пару, але вже менше - на 24,1 та 23,3 \% [3, 4]. С. О. Юркевич, Н. П. Коваленко також вважають, що в умовах Південного Степу пшеницю озиму найбільш доцільно розміщувати в сівозміні по чорному та зайнятих парах [20].

За даними Харківського НАУ, чорний пар як кращий попередник пшениці озимої доцільно замінити на зернобобові культури, які за сприятливих умов осіннього періоду вегетації пшениці практично не поступаються пару чорному [15]. Подібні результати досліджень одержано і на Полтавській ДСГДС імені М. І. Вавилова у тривалих стаціонарних дослідах з вивчення сівозмін [13].

Доведено, що в зоні Правобережного Лісостепу оптимальним попередником для насіннєвих посівів, особливо для вирощування високих генерацій насіння, є сидеральний пар [6-8].

Аналіз джерел наукової літератури свідчить, що питання вибору оптимального попередника для розміщення пшениці озимої $є$ актуальним і потребує постійного поглибленого вивчення, яке зумовлено глобальними й зональними змінами характеру кліматичних умов, коригуванням структури посі- 


\section{СІЛЬСЬКЕ ГОСПОДАРСТВО. РОСЛИННИЦТВО}

вних площ відповідно до попиту ринку на товарну продукцію тієї чи тієї культури.

Мета досліджень - з'ясувати вплив різних попередників, рівня удобрення на водоспоживання посівів пшениці озимої та ії продуктивність.

Завдання дослідження: вивчити вплив різних попередників на використання вологи посівами пшениці озимої; дослідити вплив системи удобрення та попередників на урожайність зерна пшениці озимої.

\section{Матеріали і методи досліджень}

Дослідження проводили впродовж 2018-2020 pp., на базі Полтавської ДСГДС імені М. І. Вавилова. Грунт дослідного поля - чорнозем типовий малогумусний важкосуглинковий, із вмістом гумусу в шарі 0-20 см 4,2 \%; азоту, що легко гідролізується - 6,9 мг/100 г грунту (за Тюріним та Кононовою); $\mathrm{P}_{2} \mathrm{O}_{5}$ в оцтовокислій витяжці - 12,7 мг/100 г грунту (за Чириковим); обмінного калію - 17,4 мг/100 г грунту (за Масловою), реакція грунтового розчину слабокисла (рН сольової витяжки - 6,3).

Схема досліду включала 4 варіанти трипільних сівозмін, у яких попередниками пшениці були: чорний пар, горох на зерно, пшениця озима, еспарцет на зелений корм. Повторність досліду чотириразова. Розміщення варіантів і повторень систематичне. Посівна площа ділянки $172,8 \mathrm{~m}^{2}$, облікова -

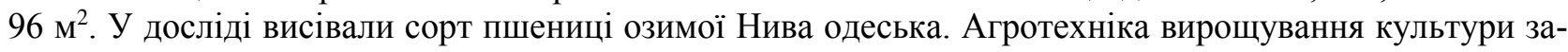
гальноприйнята для агроформувань регіону.

Для розв'язання поставлених завдань був проведений комплекс спостережень, обліків і аналізів. Вологість грунту визначали термостатно-ваговим методом на час відновлення весняної вегетації та збирання пшениці озимої [10].

Облік урожайності проводили на кожній ділянці методом суцільного обмолоту комбайном SAMPO-500, з подальшим зважуванням, визначенням вологості зерна та частки незернової домішки.

Математично-статистичний обробіток результатів досліджень проводили, використовуючи дисперсійний аналіз за Б. О. Доспєховим [9] з використанням програми STATISTICA 10.0.

\section{Результати досліджень та їх обговорення}

В умовах зони недостатнього зволоження Лівобережного Лісостепу України рівень забезпеченості грунту доступною вологою як на час сівби, так і впродовж періоду вегетації є одним із вирішальних чинників, які визначають ступінь реалізації продуктивного потенціалу пшениці озимої та його сталість.

Сільськогосподарські культури різняться за впливом на водний режим грунту в сівозмінах через неоднакове використанням ії з грунту для підтримання процесів життєдіяльності та формування врожаю.

У результаті досліджень, проведених упродовж 2019-2020 рр., виявили, що на час відновлення весняної вегетації найбільшими були запаси доступної вологи в 1,5 метровому шарі грунту в разі розміщення пшениці озимої по чорному пару 250,9 мм (табл. 1). У сівозміні, де парозаймаючим попередником пшениці озимої був еспарцет на один укіс, вміст вологи у грунті був меншим на 7,3 мм або на $2,9 \%$, ніж по чорному пару. За умови сівби пшениці озимої після гороху на зерно вміст доступної вологи в посівах культури поступався парозаймаючим попередникам на 6,8-13,8 мм або 2,8-5,6 \%.

1. Запаси доступної вологи в 1,5 м иарі трунту залежно від попередників пиениці озимої, середне за 2019-2020 pp.

\begin{tabular}{|c|l|c|c|}
\hline \multirow{2}{*}{$\begin{array}{c}\text { № } \\
\text { вар. }\end{array}$} & \multicolumn{1}{|c|}{ Попередники } & \multicolumn{2}{|c|}{ Вміст вологи в 1,5 м шарі груну, мм } \\
\cline { 3 - 4 } & & на час відновлення весняної вегетації & на час збирання \\
\hline 1. & Чорний пар & 250,9 & 87,5 \\
\hline 2. & Горох & 236,8 & 76,3 \\
\hline 3. & Пшениця озима & 197,7 & 116,3 \\
\hline 4. & Еспарцет на один укіс & 243,6 & 114,1 \\
\hline
\end{tabular}

Найменший вміст доступної вологи в 1,5 м шарі грунту відзначено в разі сівби пшениці озимої після пшениці озимої. На цьому варіанті досліду порівняно з розміщенням пшениці озимої по чорному пару і після гороху на зерно різниця за запасами доступної вологи у грунті на час відновлення весняної вегетації становила, відповідно, 53,9 і 39,1 мм або 21,2 і 16,5\%. Дослідження С. І. Кудрі, Н. А. Кудрі також свідчать, що в умовах недостатнього та нестійкого зволоження горох за нагромадженням доступної вологи у грунті значно перевищує інші непарові попередники [15]. 


\section{СІЛЬСЬКЕ ГОСПОДАРСТВО. РОСЛИННИЦТВО}

За умови різного набору і чергування культур у сівозмінах підвищується значимість їх біологічного впливу на нагромадження вологи у грунті і продуктивність ії використання на створення одиниці урожаю. Одержані результати досліджень свідчать, що посіви пшениці озимої у разі розміщення в сівозміні після різних попередників відрізняються між собою не тільки за кількістю використаної вологи із грунту, але й за величиною сумарного водоспоживання (табл. 2).

2. Водоспоживання посівів пшениці озимої залежно від попередників, середне за 2019-2020 рр.

\begin{tabular}{|c|l|c|c|c|}
\hline $\begin{array}{c}\text { № } \\
\text { вар. }\end{array}$ & Попередники & $\begin{array}{c}\text { Врожайність } \\
\text { зерна, т/га }\end{array}$ & $\begin{array}{c}\text { Сумарні витрати вологи за } \\
\text { вегетаційний період, т }\end{array}$ & $\begin{array}{c}\text { Сумарні витрати } \\
\text { вологи на 1 т зерна, т }\end{array}$ \\
\hline 1. & Чорний пар & 4,09 & 3638 & 889 \\
\hline 2. & Горох & 4,27 & 3677 & 861 \\
\hline 3. & Пшениця озима & 3,59 & 2815 & 801 \\
\hline 4. & $\begin{array}{l}\text { Еспарцет на } \\
\text { один укіс }\end{array}$ & 4,23 & 3228 & 801 \\
\hline
\end{tabular}

Найбільшу сумарну кількість вологи 3 грунту витрачали посіви пшениці озимої в разі сівби після гороху на зерно. За умови розміщення культури по чорному пару відзначено зменшення сумарних витрат вологи, порівняно із сівбою після гороху на $1,1 \%$. Найменше витрачали вологи посіви у разі повторного вирощування пшениці озимої в сівозміні.

Більш повну оцінку ефективності використання вологи рослинами дає коефіцієнт водоспоживання, який характеризує витрати вологи на створення одиниці сухої речовини. В наших дослідженнях коефіцієнт водоспоживання коливався в інтервалі від 784 до 889 одиниць. Верхнє значення цього показника в разі сівби культури по чорному пару, а нижнє - в разі розміщення пшениці озимої після пшениці озимої. Такі відмінності за коефіцієнтом водоспоживання посівів пшениці озимої зумовлені як запасами доступної вологи на час відновлення весняної вегетації, так і умовами росту культури, які формувалися залежно від особливостей впливу кожного з попередників.

Місце пшениці озимої та інших культур значною мірою визначає рівень їх урожаю, і врешті-решт продуктивність сівозмін. У дослідженнях кращим попередником пшениці озимої $є$ горох на зерно. В середньому за три роки (2018-2020рр.) урожайність культури після цього попередника в разі внесення під пшеницю озиму мінеральних добрив у нормі $\mathrm{N}_{50} \mathrm{P}_{50} \mathrm{~K}_{50}$ становив 4,52 т/га (табл. 3).

3. Вплив попередників на урожайність пшениці озимої, середня за 2018-2020 рр.

\begin{tabular}{|c|l|c|c|c|c|}
\hline \multirow{2}{*}{$\begin{array}{c}\text { № } \\
\text { вар. }\end{array}$} & \multicolumn{1}{|c|}{ Попередники } & \multirow{2}{*}{ Удобрення } & \multirow{2}{*}{$\begin{array}{c}\text { Урожайність, } \\
\text { т/га }\end{array}$} & \multicolumn{2}{|c|}{ до контролю } \\
\hline 1. & Чорний пар & $\mathrm{N}_{50} \mathrm{P}_{50} \mathrm{~K}_{50}$ & 4,11 & - & - \\
\hline 2. & Горох на зерно & $\mathrm{N}_{50} \mathrm{P}_{50} \mathrm{~K}_{50}$ & 4,52 & 0,41 & 9,9 \\
\hline 4. & Еспарцет на зелений корм & $\mathrm{N}_{50} \mathrm{P}_{50} \mathrm{~K}_{50}$ & 4,45 & 0,34 & 8,3 \\
\hline 3. & Пшениця озима & Гній $30 \mathrm{~T} /$ га $+\mathrm{N}_{90} \mathrm{P}_{110} \mathrm{~K}_{110}$ & 2,96 & $-1,15$ & $-27,9$ \\
\hline \multicolumn{2}{|r|}{} & 0,39 & - & - \\
\hline
\end{tabular}

Урожайність зерна пшениці після еспарцету на один укіс поступалася продуктивності ії після гороху на зерно лише на 0,07 т/га. Важливо відзначити, що у сприятливі за погодними умовами роки, вплив різних парозаймаючих культур і непарових попередників на рівень урожайності зерна пшениці озимої практично нівелювався. Відносно чорного пару як попередника пшениці озимої, то в разі сівби по ньому середньорослих сортів пшениці озимої, зокрема і Нива одеська, впродовж всіх років досліджень спостерігалось зниження урожайності зерна на 0,34-0,41 т/га порівняно з еспарцетом на один укіс і горохом. Це зумовлено різним ступенем вилягання рослин пшениці по чорному пару, наслідком якого було погіршення умов формування зерна та зростанням втрат при збиранні. Така причина зниження продуктивності посівів озимини по чорному пару найбільш чітко проявлялася в роки з інтенсивними опадами в кінці травня та у червні місяці. Одержані результати узгоджуються з дослідженнями в Уманському СГІ, згідно з якими в умовах Лісостепу чорний пар не забезпечує суттєвого росту продуктивності пшениці озимої через її схильність до вилягання [17].

У зерновій сівозміні, яка насичена пшеницею озимою на $66,6 \%$, пшеницю озиму розміщували пі- 


\section{СІЛЬСЬКЕ ГОСПОДАРСТВО. РОСЛИННИЦТВО}

сля пшениці (варіант 3). В середньому за три роки урожайність пшениці повторно розміщеної у сівозміні була на 1,15-1,56 т/га або 28,0-34,5 \% нижчою, ніж після інших попередників. Важливо зазначити, що негативний вплив попередника на продуктивність культури не зменшувався навіть у разі внесення під повторний посів пшениці озимої високих доз органічних і мінеральних добрив (гній $30 \mathrm{t} / г \mathrm{a}+\mathrm{N}_{90} \mathrm{P}_{110} \mathrm{~K}_{110}$ ). Основною причиною зниження урожайності пшениці в разі повторного розміщення ії в сівозміні $є$ погіршення фітосанітарного стану посівів та агрофізичних показників грунту.

Згідно з даними Хмельницької дослідної станції за 1973-1981 рр., сівба пшениці озимої після пшениці спричинила зниження урожайності зерна культури порівняно з розміщенням після багаторічних трав на 0,84-1,17 т/га внаслідок збільшення забур'яненості посівів та ступеня ураження рослин хворобами [16]. Погіршення водно-фізичних властивостей грунту внаслідок більш інтенсивного застосування сільськогосподарських машин у технології вирощування повторних посівів пшениці озимої відзначено в дослідженнях В. Ф. Сайка, М. Г. Лобоса, В. І. Яшовського [18].

\section{Висновки}

На основі одержаного експериментального матеріалу потрібно констатувати, що в умовах нестійкого зволоження Лівобережного Лісостепу України найвищу врожайність зерна формує пшениця озима в разі розміщення їі в сівозміні $з$ короткою ротацією після гороху на зерно та еспарцету на один укіс.

Перспективи подальшої роботи в иъьому напрямі. Перспектива подальших досліджень полягає в розширені спектру попередників пшениці озимої та вивченні їх впливу на формування ценозу бур'янів, агрохімічні показники грунту.

\section{References}

1. Boiko, P. I., Kovalenko, N. P., Hanhur, V. V., Koretskyi, O. Ye., Shapoval, I. S., Savchenko, H. I., \& Kvasnitska, L. S. (2010). Ekolohichna rol sivozmin u pidvyshchenni stiikosti ahroekosystem Lisostepu. Zbirnyk Naukovykh Prats Natsionalnoho Naukovoho Tsentru «Instytut Zemlerobstva UAAN», 3, 175-185 [In Ukrainian].

2. Boiko, P. I., Kovalenko, N. P., \& Koretskyi, O. Ye. (2010). Perspektyvy vyroshchuvannia pshenytsi ozymoi u korotkorotatsiinykh sivozminakh $\mathrm{v}$ umovakh nedostatnoho zvolozhennia. Biuleten Instytutu Zernovoho Hospodarstva, 39, 7-11 [In Ukrainian].

3. Hamaiunova, V. V., \& Lytovchenko, A. O. (2017). Osoblyvosti vodospozhyvannia pshenytsi ozymoi zalezhno vid sortiv, mistsia v sivozmini ta udobrennia v pivdennomu Stepu Ukrainy. Visnyk Dniprovskoho Ahroekonomichnoho Universytetu, 2 (44), 17-21 [In Ukrainian].

4. Hamaiunova, V. V., Lytovchenko, A. O., \& Muzyka, N. M. (2016). Znachennia poperednyka u formuvanni zernovoi produktyvnosti ozymykh kultur v umovakh Stepu Ukrainy. Visnyk Zhytomyrskoho Natsionalnoho Ahroekolohichnoho Universytetu, 1 (53), 1, 80-87 [In Ukrainian].

5. Hanhur, V. V., Kocherha, A. A., Pypko, O. S., Kabak, Yu. I., \& Len, O. I. (2020). Vplyv mineralnykh dobryv na vodospozhyvannia ta produktyvnist pshenytsi ozymoi. Visnyk Poltavskoi Derzhavnoi Ahrarnoi Akademii, 3, 54-60. doi: 10.31210/visnyk2020.03.06 [In Ukrainian].

6. Demydov, O. A., Volohdina, H. B., Zamlila, N. P., \& Koliuchyi, V. T. (2016). Reaktsiia perspektyvnykh linii pshenytsi ozymoi na umovy vyroshchuvannia. Myronivskyi Visnyk, 2, 226-240. doi: 10.21498/2518-7910.0.2016.119576 [In Ukrainian].

7. Demydov, O. A., \& Siroshtan, A. A. (2018). Vplyv pohodnykh umov i ahrotekhnichnykh zakhodiv na posivni yakosti nasinnia ta vrozhainist pshenytsi ozymoi. Ahroekolohichnyi Zhurnal, 1, 74-80. doi: 10.33730/2077-4893.1.2018.160564 [In Ukrainian].

8. Demydov, O. A., Siroshtan, A. A., Kavunets, V. P., Derhachov, O. L., Ilchenko, L. I., \& Zabolotnyi, V. I. (2017). Vplyv ekolohichnykh umov ta poperednykiv na vrozhainist, posivni yakosti i vrozhaini vlastyvosti nasinnia pshenytsi ozymoi. Myronivskyi Visnyk, 5, 152-165. doi: 10.31073/mvis201705-12

9. Dospekhov, B. A. (1985). Metodyka polevoho opyta. Moskva: Ahropromyzdat [In Russian].

10. Yeshchenko, V. O., Kopytko, P. H., Kostohryz, P. V., \& Opryshko, V. P. (2014). Osnovy naukovykh doslidzhen v ahronomii: Pidruchnyk. Vinnytsia: PP «TD «Edelveis i K»» [In Ukrainian].

11. Zhemela, H. P., \& Shakalii, S. M. (2012). Vplyv poperednykiv na vrozhainist ta yakist zerna pshenytsi miakoi ozymoi. Visnyk Poltavskoi derzhavnoi ahrarnoi akademii, 3, 20-22. doi: 10.31210/visnyk2012.03.03 [In Ukrainian]. 


\section{СІЛЬСЬКЕ ГОСПОДАРСТВО. РОСЛИННИЦТВО}

12. Kaminskyi, V.F. (2015). Sivozmina yak osnova staloho zemlekorystuvannia ta prodovolchoi bezpeky Ukrainy. Zbirnyk Naukovykh Prats Natsionalnyi Naukovyi Tsentr «Instytut Zemlerobstva NAAN», 2, 3-14 [In Ukrainian].

13. Kaminskyi, V.F., \& Hanhur, V. V. (2018). Dynamika produktyvnoi volohy v hrunti za vyroshchuvannia pshenytsi ozymoi v sivozminakh livoberezhnoho Lisostepu Ukrainy. Visnyk Poltavskoi derzhavnoi ahrarnoi akademii, 3, 11-14. doi: 10.31210/visnyk2018.03.01

14. Kovalenko, A., \& Maliarchuk, M. (2013). Chornyi par - yoho funktsiia ta utrymannia. Propozytsiia, 6, 72-73 [In Ukrainian].

15. Kudria, S. I., \& Kudria, N. A. (2009). Vplyv zernobobovykh poperednykiv na zapasy volohy v grunti ta urozhainist pshenytsi ozymoi v umovakh livoberezhnoi chastyny Lisostepu Ukrainy. Biuleten Instytutu Zernovoho Hospodarstva UAAN, 36, 32-35 [In Ukrainian].

16. Levytskyi, M. A., Salva, H. S., \& Savchenko, H. I. (1986). Produktyvnist sivozmin u zviazku z nasychenniam yikh riznymy kulturamy i dozamy dobryv. Visnyk Silskohospodarskoi Nauky, 10, 16-19 [In Ukrainian].

17. Rubyn, S. S., \& Danylevskyi, O. F., Eshchenko, V. O., \& Opryshko, V. Y. (1976). Mesto ozymoi pshenytsy. Zemledelye, 2, 41-42 [In Russian].

18. Saiko, V. F., Lobas, M. H., \& Yashovskyi, V. I. (1994). Naukovi osnovy vedennia zernovoho hospodarstva. Kyiv: Urozhai [In Ukrainian].

19. Ushkarenko, V. O., Siletskyi, V., \& Petrova, K. (2007). Vplyv poperednykiv i dobryv na urozhainist i yakisni pokaznyky zerna ozymoi pshenytsi v umovakh zroshennia. Tavriiskyi Naukovyi Visnyk, 53, 3-9 [In Ukrainian].

20. Yurkevych, Ye. O., \& Kovalenko, N. P. (2009). Osoblyvosti tekhnolohii vyroshchuvannia zernovykh kultur u rizno-rotatsiinykh sivozminakh pivdennoho Stepu Ukrainy. Visnyk Poltavskoi Derzhavnoi Ahrarnoi Akademii, 3, 28-35 [In Ukrainian].

Стаття надійшла до редакції 21.02.2021 р.

Бібліографічний опис для цитування:

Гангур В. В., Котляр Я. О. Вплив попередників на водоспоживання та продуктивність пшениці озимої в зоні Лівобережного Лісостепу України. Вісник ПДАА. 2021. № 1. С. 122-127.

(C) Гангур Володимир Васильович, Котляр Ярослав Олексійович, 2021 